\title{
血管炎症候群による椎骨動脈病変に対するエコーを用した検討
}

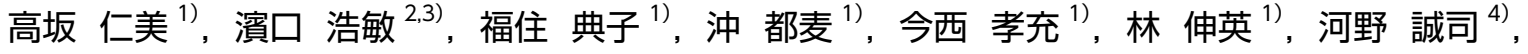 \\ 苅田 典生 ${ }^{3,4)}$
}

1) 神戸大学医学部附属病院 検査部
2) 北播磨総合医療センター 神経内科
3) 神戸大学医学部附属病院 神経内科
4) 神戸大学医学部附属病院総合臨床教育センター

\section{Study of vertebral arteritis in vasculitis syndrome using ultrasonography}

\author{
Hitomi KOUSAKA $^{1)}$, Hirotoshi HAMAGUCHI ${ }^{2)}$, Noriko FUKUZUMI ${ }^{1)}$, Tsumugi OKI ${ }^{1)}$, Takamitsu IMANISHI ${ }^{1)}$, \\ Nobuhide HAYASHI ${ }^{1}$, Seiji KAWANO ${ }^{3)}$, Fumio KANDA ${ }^{4)}$ \\ 1) Department of Clinical Laboratory, Kobe University Hospital \\ 2) Department of Neurology, Kita-Harima Medical Center \\ 3) Integrated Clinical Education Center, Kobe University Hospital \\ 4) Department of Neurology, Kobe University Hospital
}

\begin{abstract}
Purpose: In Takayasu's arteritis and temporal arteritis, vascular inflammation located at sites other than the common carotid artery and subclavian artery has not been adequately investigated. This study examined inflammatory images of the vertebral artery (VA) using ultrasonography.

Methods: We examined 54 patients (108 arteries), including 29 patients (58 arteries) with Takayasu's arteritis and 25 patients (50 arteries) with temporal arteritis), who underwent carotid ultrasonography. The frequency and properties of VA lesions were compared between patients with Takayasu's arteritis and temporal arteritis.

Results: Two of the 58 arteries with Takayasu's arteritis showed a halo sign, two had stenosis, and three had occlusion. Eleven of the 50 arteries with temporal arteritis had a halo sign, and none showed stenosis or occlusion. Stenosis and occlusion were more common in VA lesions of patients with Takayasu's arteritis, whereas halo sign was more common in patients with temporal arteritis.

Discussion: By the time of ultrasonography, Takayasu's arteritis had often already progressed to the stage of VA stenosis and occlusion, whereas temporal arteritis may be identified at an earlier stage.

Conclusion: Ultrasonographic characteristics of VA lesions differ between Takayasu's arteritis and temporal arteritis.
\end{abstract}

Keywords: Takayasu’s arteritis, temporal arteritis, vertebral artery abnormalities

(Received February 5, 2015; Accepted June 23, 2015)

\section{はじめに}

\footnotetext{
全身血管炎は, 血管炎を主病変とする一次性血管炎と, 他疾患に血管炎を伴う二次性血管炎があり ${ }^{1)}$ ，大血管炎 の代表は高安動脈炎 ${ }^{2)}$ と側頭動脈炎 ${ }^{3)}$ である。いずれも 頭頸部動脈への波及はよく知られているが，高安動脈炎 では鎖骨下動脈から総頸動脈が炎症の中心であるのに対 し，側頭動脈炎では側頭動脈が炎症の中心である。しか
}

し，他の頸部血管病変についてはあまり報告されていな い. 今回われわれは，椎骨動脈 (vertebral artery; VA) に着目し，高安動脈炎および側頭動脈炎における，VA への炎症の波及とその性状について頸部エコー検査を用 いて検討したので報告する。

\section{対象亡方法}

2005 年 6 月から 2014 年 12 月まで臨床的に高安動脈 
炎および側頭動脈炎と診断した症例のうち，頸部エコー 検査を施行した高安動脈炎 29 例 58 血管（平均年齢 $41.4 \pm 17.6$ 歳) および側頭動脈炎 25 例 50 血管（平均 年齢 $74.5 \pm 7.2$ 歳) を対象とした。診断基準については, 高安動脈炎は血管炎症候群の診療ガイドライン ${ }^{1 ）}$, 側頭 動脈炎についてはアメリカリウマチ学会 (American College of Rheumatology; ACR) の診断基準 ${ }^{4)}$ を用いた.

方法は，高安動脈炎と側頭動脈炎において，年齢，男 女比, 動脈硬化危険因子の有無（高血圧, 糖尿病, 高脂 血症，契煙），採血データにおける炎症反応（WBC， $\mathrm{CRP}$ ），赤血球沈降速度（erythrocyte sedimentation rate; ESR)，発症からエコー検査までの期間を対比した。エ コー装置は Aplio SSA-700A（東芝メディカルシステム ズ，杤木)，リニア型探触子 $7.5 \mathrm{MHz}$ および $12 \mathrm{MHz}$, 深 部の観察の際には $6 \mathrm{MHz}$ を使用し，Carotidの設定を用 いて深度 3〜 4cm で仰臥位にて観察した。 B モードで 両側 VA の短軸・長軸像を, 起始部より C4 横突起部ま で確認後, カラードプラ画像を用いて異常の有無を確認 した. VA 病変は, 正常, 炎症, 狭窄, 閉塞に分類し, 以下のとおりに規定した。

正常例：異常なし. 炎症例：外膜周囲の低輝度変化 （halo sign）を認める，もしくは全周性の内中膜複合体 (intima-media complex; IMC) 肥厚（halo を認めない症 例において長軸径狭窄率 $50 \%$ 以下）を認める。狭窄例： halo を認めない症例において長軸径狭窄率 $50 \%$ 以上, もしくは狭窄部の前後の血流速度変化が 2 倍以上 ${ }^{5)}$, ま たは狭窄部位のカラードプラ画像上でモザイクパターン を認め, 狭窄前後での血流波形の変化の有無などから総 合的に判断. 閉塞例 : B モードで内腔を認めず，カラー ドプラ画像，パルスドプラ法で血流を認めない，とそれ ぞれ規定した.

狭窄例と閉塞例については CT，3D-CTA，MRA な どでも確認した。 なお，両側で病変が違う症例について は各々の血管で評価した，椎骨動脈が描出できなかった 症例については本検討から除外した。また，鎖骨下動脈 狭窄·閉塞に伴う椎骨動脈血流の逆流波形例についても, 椎骨動脈病変が合併していない場合は正常例とした。

両者の臨床像およびエコー所見の比較については, Mann-Whitney U 検定および $\chi$ 二乗検定を用いて評価を 行い, $p<0.05$ 以下を有意差ありと判断した。

\section{結果}

高安動脈炎と側頭動脈炎の臨床像について対比した (Table 1). 高安動脈炎に比べ，側頭動脈炎では有意に 高齢者が多く，ESR高值であった。症状出現から頸部 エコー検査までの期間については，高安動脈炎で有意に 期間が長かった。
Table 1 Clinical feature

\begin{tabular}{lccc}
\hline & $\begin{array}{c}\text { Takayasu's } \\
\text { arteritis }\end{array}$ & $\begin{array}{c}\text { Temporal } \\
\text { arteritis }\end{array}$ & $\boldsymbol{p}$ value \\
\hline Age & $41.4 \pm 17.6$ & $74.5 \pm 7.2$ & $<0.001$ \\
Sex $(\mathrm{M}: \mathrm{F})$ & $2: 27$ & $4: 21$ & 0.2885 \\
HT $(\%)$ & 37.0 & 56.0 & 0.1705 \\
DM $(\%)$ & 10.3 & 20.0 & 0.3193 \\
HL $(\%)$ & 20.7 & 24.0 & 0.7705 \\
Smoking $(\%)$ & 16.7 & 32.0 & 0.7632 \\
ESR $(\mathrm{mm} / \mathrm{h})$ & 40.0 & 96.0 & $<0.001$ \\
WBC $(/ \mu \mathrm{l})$ & 41.4 & 32.0 & 0.4767 \\
CRP $(\mathrm{mg} / \mathrm{dl})$ & 58.6 & 96.0 & 0.0014 \\
Period from onset to & $101.0 \pm 122.6$ & $3.9 \pm 3.8$ & $<0.001$ \\
examination (month) & & &
\end{tabular}

Table 2 Frequency of vertebral artery findings on Takayasu's arteritis and temporal arteritis

\begin{tabular}{|c|c|c|c|c|}
\hline $\begin{array}{l}\text { Vertebral artery } \\
\text { findings }\end{array}$ & $\begin{array}{c}\text { Takaya- } \\
\text { su's } \\
\text { arteritis } \\
\mathrm{n}=58(\%)\end{array}$ & $\begin{array}{c}\text { Temporal } \\
\text { arteritis } \\
n=50(\%)\end{array}$ & total & $p$ value \\
\hline Normal & $51(87.9)$ & $39(78.0)$ & 90 & 0.1673 \\
\hline Anflammation & $2(3.4)$ & $11(22.0)$ & 13 & 0.0031 \\
\hline Abnormal Stenosis & $2(3.4)$ & & 2 & 0.1850 \\
\hline Occlusion & $3(5.2)$ & $0(0)$ & 3 & 0.1029 \\
\hline
\end{tabular}

VAの計測は全例で両側描出可能であった. VA病変は, 高安動脈炎では 29 例 58 血管中 51 血管 $(87.9 \%)$ で正常, 炎症例は 2 血管 $(3.4 \%)$, 狭窄例は 2 血管 $(3.4 \%)$, 閉 塞例は 3 血管 $(5.2 \%)$ に認めた。一方，側頭動脈炎で は 25 例 50 血管中 39 血管 $(78.0 \%)$ で正常，炎症例は 11 血管 $(22.0 \%)$ を認めたが，狭窄例や閉塞例は認め なかった（Table 2)．炎症例については有意差をもって 側頭動脈炎で多かった。

両者の異常所見の代表例をそれぞれ提示する（Fig.1， 2)．高安動脈炎のVA 炎症例では，血管外膜周囲に halo 像を認め (Fig.1A, B 矢印)，VA狭窄例では，C5-C6 横 突起間のカラーシグナルがモザイクパターンを示し，最 大血流速度が $1.7 \mathrm{~m} / \mathrm{sec}$ と加速していた（Fig.1C 矢印）。 VA 閉塞例では，カラーシグナルが欠損していることが 観察できた (Fig.1D 矢印)。側頭動脈炎のVA炎症例では, 側頭動脈 (Fig.2A 矢印)，VA (Fig.2B 矢印) のいずれに も血管外膜周囲に halo 像を認めた。

\section{考察}

高安動脈炎と側頭動脈炎はいずれも大動脈から全身の 血管に炎症を及ぼすことが知られている。なかでも頸部 エコー検査での異常所見を契機に発見される場合も少な からず存在する。しかし，血管炎でみられるエコー画像 において，どのような波及パターンを呈するのかについ て詳細な検討はない. 血管炎のエコー所見における特徵 
A

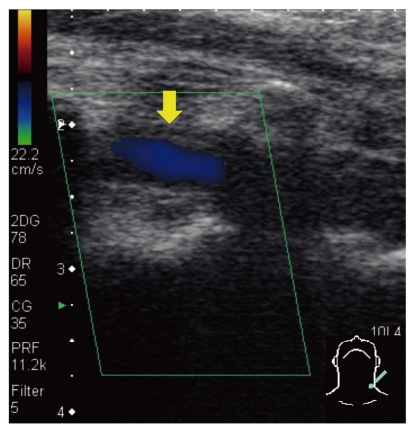

C

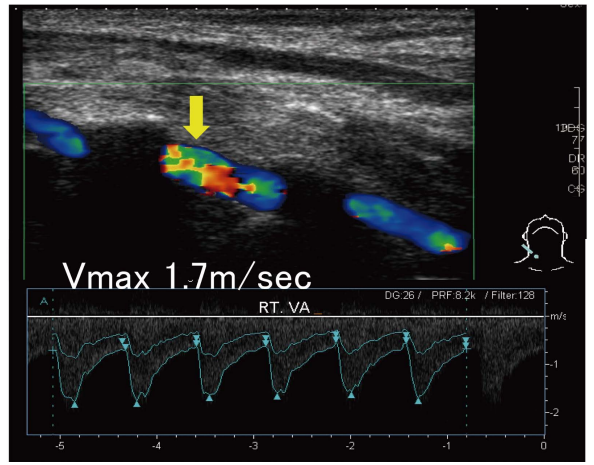

B

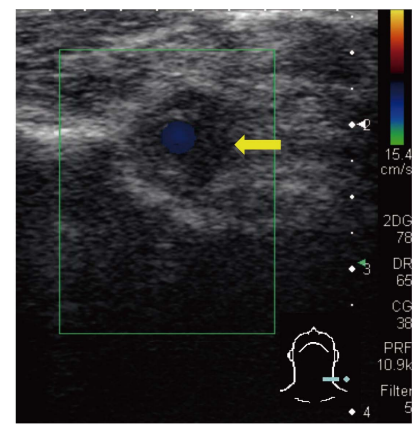

$\mathrm{D}$

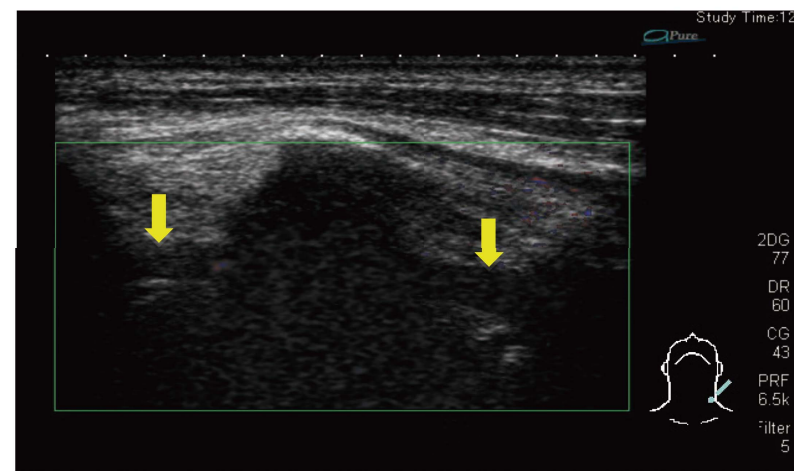

Fig.1 B-mode and Doppler color flow images in Takayasu's Arteritis

A, B : Long axis and axial view of inflammatory changes of left VA (yellow arrows)

$\mathrm{C}$ : Stenosis of right VA (yellow arrows). The peak systolic velocity was increased to $1.7 \mathrm{~m} / \mathrm{sec}$.

$\mathrm{D}$ : Occlusion of left VA (yellow arrows)

として，炎症の波及は内膜側へ波及し，IMC 肥厚から 縮窄・狭窄・閉塞に向かうパターンと, 外膜側へ波及し, 蛇行・拡張・瘤形成に向かうパターンが考えられる，特 に高安動脈炎では，鎖骨下動脈から総頸動脈にかけての 全周性の IMC 肥厚 ${ }^{6}$ が特徵的な所見として認められ, 側頭動脈炎では主に側頭動脈における halo sign とよば れる血管外膜側の全周性の低輝度病変が特徵的な所見と して知られている ${ }^{5778)}$. エコー所見でみられる形状の 違いは明らかではないが, 総頸動脈で IMC 肥厚を認め る症例報告もあり，いずれも炎症像の一形態として考え られている9

高安動脈炎㧍よび側頭動脈炎の頸部領域への炎症の波 及は，おもに鎖骨下動脈や総頸動脈への波及が多くみら れるが，高安動脈炎と側頭動脈炎でその頻度はやや異な る。VAに着目すると，炎症の波及頻度について，McKinnon らは，両者ともほほ同率で $10 \%$ 程度認められる と報告している ${ }^{10)}$.

高安動脈炎については, Cantuらは 37 例中狭窄およ び閉塞例が各々7例（19％）であったと報告してお $り^{11)}$ ，Kerr らは，血管造影による報告であるが，60 例 中 $35 \%{ }^{12)}$ で VA 病変が認められると報告している。こ れらはわれわれの検討よりも高頻度の報告であった。一 方，側頭動脈炎において，超音波検査を用いた VA病変 の検討については，われわれが渉猟した限りではわずか に散見されるのみであった. Pfadenhauerらは93例中 狭窄閉塞例が $13 \%$ と多く, halo sign は $2 \%$ のであっ
A

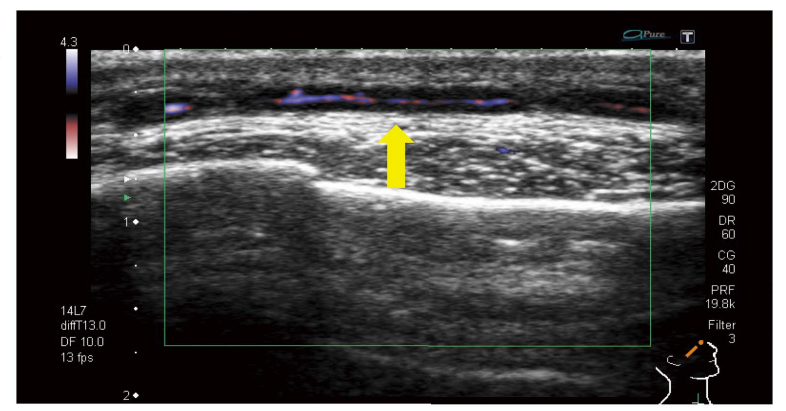

B

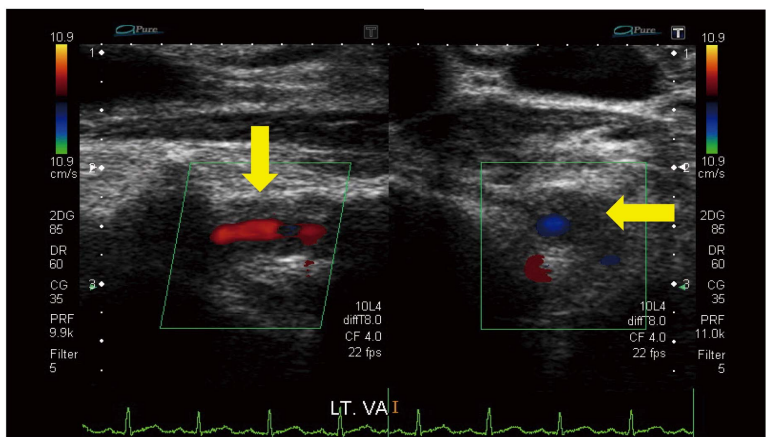

Fig.2 B-mode and Doppler color flow images in Temporal Arteritis

A: inflammatory changes of right temporal artery (yellow arrows)

B: inflammatory changes of left VA (yellow arrows)

たと報告している ${ }^{13)}$. Schumidt らは33 例中閉塞と halo sign, 各々 3\%ずつ認められた ${ }^{14)}$ と報告している.し かし, われわれの検討では閉塞狭窄例はなく, halo sign が $22.0 \%$ と多く認められた。このことは, 超音波装置 の性能向上に伴い, 深部に位置する椎骨動脈が明瞭に描 


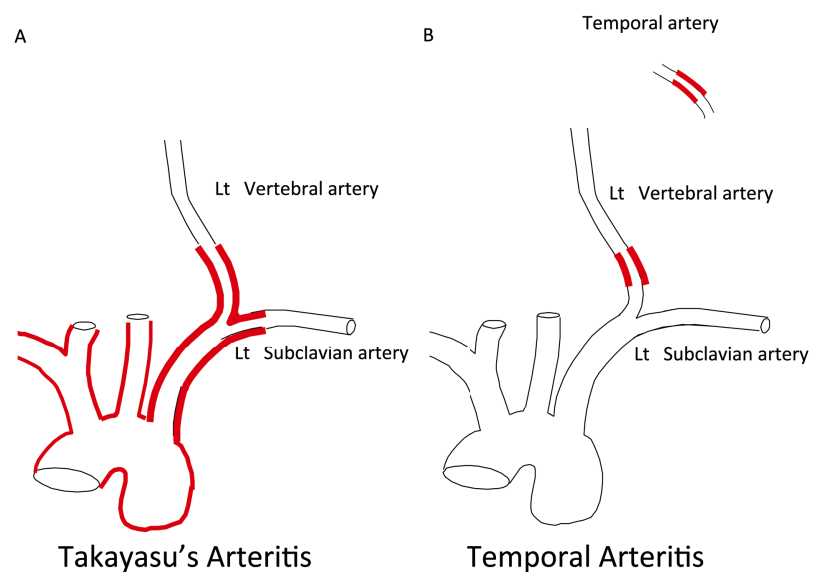

Fig.3 Pattern of vasculitis spreading to head and neck vessels

A: Takayasu's arteritis spread continuously from the aorta, subclavian artery

B: Temporal arteritis spread intermittently temporal artery or vertebral artery

出できるようになったこと, 発症早期から椎骨動脈病変 を疑って評価できたためと考える。

今回のわれわれの検討では, 高安動脈炎では狭窄・閉 塞が多かったのに対し，側頭動脈炎では halo sign が有 意に多く，狭窄や閉塞は認めなかった。このことは，高 安動脈炎拉よび側頭動脈炎のVAへの炎症の波及パター ンも関与していると推測される，高安動脈炎では，大動 脈や鎖骨下動脈に炎症の主座があり，初期は外膜側への 波及をきたす。ささらに内膜側へ進展をきたすと症状が出 現し, IMC 肥厚, 狭窄や閉塞に進展していくと考えら れる. 今回の検討では, 症状が出現してから長期間経過 した状態で検査を行っているため，すでに進展している 病巣を観察しているものと推測される。より発症早期に 評価することができればもう少し炎症像が評価できたか もしれない，一方，側頭動脈炎では，初期に外膜側への 波及をきたすが，高安動脈炎と違い，この段階で症状が 出現し, 頸部エコー検査で早期病変を観察できたと推測 する，さらに，病変が進展する前に治療を開始している ため, 狭窄や閉塞に至らなかったと推測する。

また，高安動脈炎では，主に大動脈・鎖骨下動脈から の連続した進展波及が考えられる（Fig.3A）ため，ある 程度時間が経過してから VA に病変が出現してくると考 えられる。一方，側頭動脈炎では，連続性ではなく限局 した病変が複数部位で出現し, 椎骨動脈にも単独の炎症 波及をきたすと考えられ（Fig.3B），その結果早期から の VA 病変の出現に至ったものと考えられる。 これらの 違いが, 高安動脈炎と, 側頭動脈炎の椎骨動脈病変の工 コー所見の違いにつながったと推測する。

今回の検討は, いずれも少数例の検討であったため, 発症直後からのVA 進展がどのように変化するかまでは
評価困難であった。脳卒中症例における精査の中で, VAの halo sign を契機に側頭動脈炎と診断され，重症度 と関係するという報告もあり，VAの halo signは重要な 評価項目といえる ${ }^{15)}$. 今後さらなる症例の蓄積が待た れる。

\section{結語}

血管炎症候群の椎骨動脈への波及については, 高安動 脈炎では，閉塞・狭窄像が中心であり，傊頭動脈炎は炎 症像が中心であった，大型血管炎に打いて，椎骨動脈へ の進展は異なった機序が関与していると推測する.

本論文の要旨は, 第 30 回日本脳神経超音波学会総会 （2011 年 7 月, 埼玉）にて発表したものを再集計した.

\section{-文献}

1) 循環器病の診断と治療に関するガイドライン 2006-2007 年度 合同研究班：血管炎症候群の診療ガイドライン.Circ J $2008 ; 72$ (Suppl.IV): 1253-1318.

2) 小林靖, 沼野藤夫: 高安動脈炎, 長澤俊彦 (監), 橋本博史 (編)： 血管炎，東京：朝倉書店，2001，p192-198.

3）秋月正史：側頭動脈炎, 長澤俊彦 (監), 橋本博史（編）：血 管炎, 東京：朝倉書店, 2001, p199-202.

4) Hunder GG, Bloch DA, Michel BA, et al.: The American College of Rheumatology 1990 criteria for the classification of giant cell arteritis. Arthritis Rheum 1990; 33: 1122-1128.

5) Schmidt WA, Kraft HE, Vorpahl K, et al.: Color duplex ultrasonography in the diagnosis of temporal arteritis. N Engl J Med 1997; 337: 1336-1342.

6) Maeda H, Handa N, Matsumoto M, et al.: Carotid lesions detected by B-mode ultrasonography in Takayasu's arteritis: "macaroni sign" as an indicator of the disease. Ultrasound Med Biol 1991; 17: 695-701.

7）濱口浩敏, 今西孝充, 高坂仁美, 他：診断, 治療効果の判定 に側頭動脈エコー検査が有用であった側頭動脈炎症例の検 討. Neurosonology 2008; 21: 107-111.

8) Pfadenhauer K, Weber H: Duplex sonography of the temporal and occipital artry in the diagnosis of temporal arteritis. A prospective study. J Rheumatol 2003; 30: 2177-2181.

9）沖都麦, 濱口浩敏, 今西孝充, 他 : エコー上総頸動脈にmacaroni signを呈した側頭動脈炎の 2 例。脈管学 2012；52； 259-263.

10) Maksimowicz-McKinnon K, Clark TM, Hoffman GS: Takayasu arteritis and giant cell arteritis : A spectrum within the same disease? Medicine 2009; 88: 221-226.

11) Cantu C, Pineda C, Barinagarrementeria F, et al.: Noninvasive cerebrovascular assessment of Takayasu arteritis. Stroke 2000: 2197-2202.

12) Kerr GS, Hallahan CW, Giordano J, et al.: Takayasu arteritis. Ann Intern Med 1994; 120: 919-929.

13) Pfadenhauer K, Esser M, Berger K: Vertebrobasilar ischemia and structural abnormalities of the vertebral arteries in active temporal arteritis and polymyalgia rheumatica-An ultrasonographic case-control study. J Rheumatol 2005; 32: 2356-2360.

14) Schmidt WA, Natusch A, Möller DE, et al.: Involvement of peripheral arteries in giant cell arthritis: A color Doppler sonography study. Clin Exp Rheumatol 2002; 20: 309-318.

15) García-García J, Ayo-Martín Ó, Argandoña-Palacios L, et al.: Vertebral artery halo sign in patients with stroke: A key clue for the prompt diagnosis of giant cell arteritis. Stroke 2011; 42: 3287-3290. 